\title{
Payment system of urban family physician programme in the Islamic Republic of Iran: is it appropriate?
}

Leila Doshmangir, ${ }^{1,2}$ Arash Rashidian, ${ }^{3,4}$ Amirhossein Takian, ${ }^{3,5}$ Parinaz Doshmangir ${ }^{1}$ and Hakimeh Mostafavi ${ }^{6}$

${ }^{1}$ Tabriz Health Services Management Research Center, School of Management and Medical Informatics, Tabriz University of Medical Sciences, Tabriz, Islamic Republic of Iran. ${ }^{2}$ Social Determinants of Health Research Center, Management and Safety PRomotion Research Institute, Tabriz University of Medical Sciences, Tabriz, Islamic Republic of Iran. ${ }^{3}$ Department of Health Management and Economics, School of Public Health, Tehran University of Medical Sciences, Tehran, Islamic Republic of Iran. ${ }^{4}$ Department of Information, Evidence and Research, World Health Organization Regional Office for the Eastern Mediteranean, Cairo, Egypt. ${ }^{5}$ Health Equity Research Centre (HERC), Tehran University of Medical Sciences, Tehran, Islamic Republic of Iran. ${ }^{6}$ Health Economy, Standard and Health Technology Department, Vice-Chancellor's Office in Treatment Affairs , Shahid Beheshti University of Medical Sciences, Tehran, Islamic Republic of Iran (Correspondence to: Hakimeh Mostafavi: hakimeh_mostafavi@yahoo.com).

\begin{abstract}
Background: The payment system is pivotal in implementing policies in the health sector. Equitable access to healthcare is the main principle of the payment system.
\end{abstract}

Aims: This study aimed to investigate aspects of the payment system in the urban family physician programme (FPP) in the Islamic Republic of Iran.

Methods: This was a qualitative study. We obtained data from key informants and both formal and grey literature. We used content analysis for data analysis.

Results: A range of concepts was explored related to the payment system of the FPP. By merging similar expressions, we categorized the findings into four main themes including: payment method, payment criteria and incentives, payment process and amount of payment.

Conclusions: FPP is required to follow convenient implementation methods. The mechanisms of payment in the health sector are weak and have no transparency. A blurred combination of criteria makes an unclear process for determining the payment mechanisms. It is recommended that the opinions of key stakeholders be taken into consideration prior to developing payment mechanisms and financial incentives.

Keywords: family physicians, healthcare access, Iran, payment system, urban area

Citation: Doshmangir L; Rashidian A; Takian A; Doshmangir P; Mostafavi H. Payment system of urban family physician programme in the Islamic Republic of Iran: is it appropriate? East Mediterr Health J. 2018;24(7):611-617. https://doi.org/10.26719/2018.24.7.611

Received: 21/04/16; accepted: 22/05/17

Copyright (C) World Health Organization (WHO) 2018. Some rights reserved. This work is available under the CC BY-NC-SA 3.o IGO license (https:// creativecommons.org/licenses/by-nc-sa/3.o/igo).

\section{Introduction}

Establishment of the family medicine programme (FMP) on the basis of an appropriate referral system is one of the main strategies to increase access and improve efficiency of healthcare systems globally $(1,2)$. Payment mechanisms and financial incentives to reimburse family physicians (FPs) play a major role in improving the quality of healthcare services. Hence, well-designed applications are required to measure and allocate such incentives for improving practices (3). Moreover, the financial incentives have a major role in the specialty that medical students choose in the future (4).

Current payment methods worldwide include fee for service (FFS), salary, capitation, pay for performance (PFP), and some other mixed methods; each with its strengths and weaknesses. Payment methods affect both provider and purchaser of the services (5). Capitation means that the number of people who refer to health centres is the main factor for payment. In other words, just visiting the patients is a measure for payment without any attention to results of treatment (6). Capitation may foster effectiveness of healthcare services through proper mechanisms to select patients.

FFS may increase the quality of provided services, while increasing the cost (7). FFS is the main mechanism for payment in public hospitals. Some believe that FFS prevents low-quality services, and patients may access optimal treatments (8). This method is applied in the United States of America (USA) but it has not been successful and has resulted in high costs (9).

Salary is a continuous way to reimburse health workers and professionals. It is known to decrease the level of relationship between the physician's income and type of services offered to patients, which could affect service quality.

PFP is a common method in primary health care ( $\mathrm{PHC})$ network, by which practitioners are paid on the basis of their achievements. There is a lack of evidence for the relationship between payment methods and the quality of health services (10). Hence, mixing and matching and switching among payment methods in health systems are common to meet health policy goals (11), and many health systems prefer to apply a mix of payment methods to avoid extra costs (12). 
There is little information about payment systems for FMP in the Islamic Republic of Iran. Therefore, this study aimed to identify an appropriate payment system for the urban family physician programme (FPP) in the Islamic Republic of Iran.

Payment mechanisms involve some methods to transfer funds from a buyer, that is, the government, insurance company, or patient, to healthcare providers, namely, individual physicians or institutes (13). The health systems in different countries have applied diverse payment methods. For instance, while FFS is the dominant method in Australia, PFP has been used to improve the quality and outcome of health services since 1998 (14). Similarly, FFS is often used for reimbursement of $90 \%$ of PHC physicians in the USA (15). FFS as well as the state fee schedules are applied In Canada (16). Similarly, FFS was executed in 2008 in Ghana, where no standard fee schedules were in place (17). In contrast, France has a national social insurance system that pays a fixed fee per each registered patient to doctors (18). In Turkey, all physicians receive salaries and bonuses, while physicians who work in deprived areas may receive an additional reward (19). These experiences suggest that there are different approaches in health payment systems globally. The most common payment methods are outlined by Quinn (12).

The aim to enhance universal access to health care services led to establishment of the PHC network in the Islamic Republic of Iran in 1984 (20). Community health workers and general practitioners are the main members of PHC system. Especially in rural areas, the PHC has a critical role in delivering services to people $(21,22)$.

PHC has contributed to significant improvement of many health indicators: child and maternal mortality, life expectancy and control of infectious diseases in the Islamic Republic of Iran $(23,24)$. Some of the most important health index improvements are shown in Table 1.

Similar to health systems in many developing countries, the Iranian system has faced several emerging problems, with major causes of death being noncommunicable diseases and traffic accidents (23). In addition, the quality and efficiency of healthcare services have been questioned for not meeting the requirements of demographic transition, public expectations and changes in disease patterns (13). To increase equitable

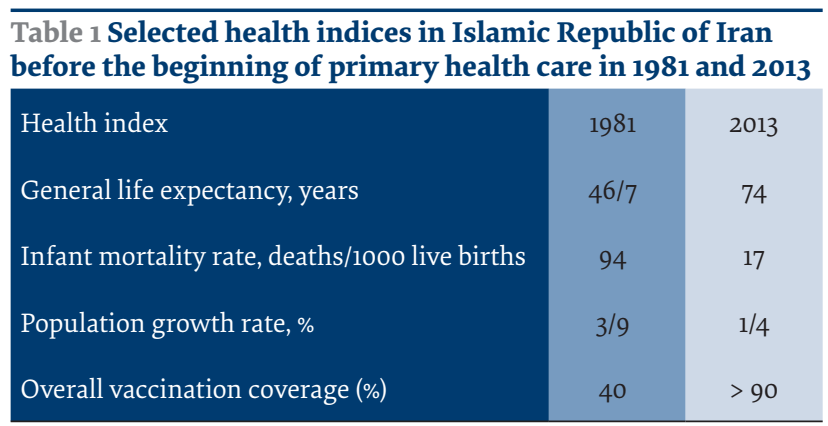

access to health services of people residing in villages and small towns of $<20000$ inhabitants, the Iranian Ministry of Health and Medical Education (MOHME) seized the opportunity of launching the FMP (13). The FMP was endorsed by the 4th and 5th National Development Plans, and assigned a general practitioner to a population of 2000-4000 (20) as the manager of the health team. Ten years into its implementation, the FMP has expanded to larger cities, and all urban settings of two pilot provinces since 2011.

This study aimed to investigate aspects of the payment system in the urban FPP of the health system in the Islamic Republic of Iran.

\section{Methods}

\section{Study design}

This was a qualitative study using three main data sources: interviewing nine key informants, reviewing literature and searching national documents, and national web sites. The study was conducted from December 2012 to November 2013, when national expansion of the FPP in the Islamic Republic of Iran was announced.

\section{Sampling and data collection}

We selected key informants that had direct participation in PHC management and development of the FPP payment system. We conducted face-to-face interviews with nine key informants from MoHME, two medical universities, insurance companies, and three FPs. All interviews were conducted in the interviewees' offices by L.D. using a semistructured guide. We asked questions about current payment mechanisms and the views of the interviewees about these mechanisms. All interviews were recorded and transcribed. The average time of the interviews was 50 minutes. Because of the limited number of managers who were informed about the FPP payment system, we only interviewed nine people. In other words, purposive sampling was applied to identify the key informants, who had valuable experiences about the FMP.

We searched several websites to select relevant documents (http://www.salamatnews.com, http://www. salamatiran.com, http://rc.majlis.ir/fa/parliament,http:// irimc.net /default.aspx, http://www.irna.ir, http:// tebyannews.comhttp://www.webda.ir, http://www.tums. ac.ir, http://www.dolat.ir). We considered the following criteria for selecting the websites: national websites well known for health policy issues; websites of institutes involved in FPPs; and websites of the three pioneer medical universities in the country. We also purposefully selected some comprehensive and appropriate news, which was directly or indirectly related to FPPs.

The main data collection tool was a researcher-made form that functioned as our document analysis worksheet. In addition, we used other document-based data sources including: legislative laws, administrative/executive regulations, payment procedures, guidelines, reviews, reports, policy statements, and minutes of meetings 
and documents related to focus groups and round table discussions from organizations, such as MoHME, Iranian Parliament, Iranian Medical Association and health insurance corporations. Urban FPP was the subject of major national debate at the time of data collection, which led to collection of a large volume of data. After removing the duplicates, we gathered 728 documents, which were classified based on their type. We designed some tables and then inserted the related news and statements in the tables. In this phase two authors (L.D. and P.D.) extracted the appropriate date from documents and H.M. checked and controlled the extracted data.

\section{Data analysis}

All the documents and transcribed interviews were imported to MAXQDA version 10 and were coded. The data were analysed through qualitative content analysis (25). The analysis included reading the documents and transcripts several times and then coding them inductively and deductively. Two authors (L.D. and H.M.) coded the data, and discussed them in continuous sessions and A.R. rechecked the themes. Finally, the themes and concepts were finalized according to the suggestions of the research team members.

\section{Ethical consideration}

We obtained verbal consent from interviewees and ensured confidential and anonymous data collection, analysis and reporting. The researchers tried their best to be neutral during all phases of the study. The study was approved by the Ethics Committee of Tehran University of Medical Sciences and registered in the Knowledge Utilization Research Center (Registration Code: 19704).

\section{Results}

We identified four main themes that are considered as pillars in developing an appropriate payment system for the FPP in the Islamic Republic of Iran: payment method, payment criteria and incentives, payment process and amount of payment.

\section{Payment method}

We revealed lack of consensus among various stakeholders on the current FPP payment methods in rural Islamic Republic of Iran. Some participants suggested that payment should be based on capitation, while others stated that FFS and PFP are appropriate ways to pay service providers. Some interviewees preferred salary and bonus as the most appropriate payment methods in the implementation of the FPP. Some participants stated that salaries guaranteed a monthly income for doctors and other health team members. Others pointed out that it was imperative to have additional payments per capita for some special tasks, such as diagnosis, treatment and surveillance of target diseases. Several interviewees highlighted the importance of designing a payment system based on mixed payment methods, including a combination of capitation, FFS and bonus.
According to participants, $40 \%$ of the payment to FPs was based on their performance. This led to $80-120 \%$ variation in payment to FPs according to their assessment scores. Some participants mentioned the benefits of the mixed payment and considered it the best type of payment system worldwide. Participants who endorsed mixed payment methods expressed their concern about physicians who worked in day clinics and were paid a salary or capitation, while those who worked in night clinics were paid based on FFS.

\section{Payment criteria and incentives}

Development of measures to determine the payment criteria was an important factor to avoid unhealthy competition among physicians. Various criteria are used for reimbursement of FPs, such as size of population covered, career, length of residence in a city, and age and sex of the patients referred. Moreover, payments were higher for covering elderly patients and pregnant women, as well as working in poor and deprived regions. Another issue was FPs being penalized; for instance, if they were unable to register 2500 people, their income would be reduced. This led some participants to criticize the existing criteria for paying FPs in some regions and to call for more realistic payment models.

Midwives are part of the family medicine team. The FPP has failed to employ midwives, as they were forced to conduct activities such as pharmaceutical services, injections, dressings and other inappropriate services. In addition, insufficient income was another major barrier to attracting midwives to join the FPP.

\section{Amount of payment}

Amount of payment was regarded as a critical factor for developing an appropriate culture and increasing public interest in FPPs. Some interviewees stated that FPs were important in developing a referral culture in the Islamic Republic of Iran. Some participants believed that measures should be taken to avoid the significant income difference between the members of the health team (e.g., general physicians and specialists), while PFP could be implemented to incentivize good practice. The current payment system considered an annual increase of $1 \%$ for up to 20 years of experience. Also, in the first 5 years of implementing the FPP, $1-3 \%$ will be added to the payment of physicians. For practices that have registered critical populations, that is, people aged $>60$ years, children aged $<5$ years, pregnant women, and patients with chronic diseases, the payment for FPPs will increase by $20 \%$ per capita.

Some participants expressed major concerns about the amount of per capita payment to FPs, branding it low as well as unfair. In addition to direct costs of running their practices, such as living accommodation, human resources, equipment and administration, FPs were also responsible for other costs that were not included in their compensation, such as differential cost of premises in the city, as well as hidden costs (due to the nature of the FPP), 
such as travel for personnel to meetings, and follow-up through telephone contact.

Some participants claimed that implementation of the FPP was a means to generate income for FPs. In other words, discrimination in the salary payment system or inequitable payment to various groups of physicians, resulted in planning for the FPP, as a new way to increasing the income of some physicians. However, this claim requires more evaluation.

\section{Process of payment}

To motivate the health team members to deliver health services, the FPP has scheduled PFP. This means that $80 \%$ of the salary is fixed, while the remaining $20 \%$ is based on evaluation score. In addition, an extra $20 \%$ incentive is considered for each physician who covers a high proportion of children aged $<5$ years or pregnant women, as well as patients $>60$ years.

Some participants were concerned about the payment inconsistency among various levels of the FPP. In other words, they believed that physicians received different payments at each level and in the private and public sectors.

\section{Discussion}

In 2013, MoHME created the opportunity for launching the FMP in the Islamic Republic of Iran to increase equitable access to health services. Undoubtedly, the payment system has an important role in providing the appropriate health services. The experiences of FPP in other countries show a wide range of parallel reforms to bring the cost of health services down considerably $(26,27)$.

Payment systems have to adapt to a hierarchy of policy priorities and practical financial considerations to meet the goals of equitable access and affordable health services. In other words, selected payment systems and applied incentives should be coordinated with the major goals of the health system and also improve the clinical knowledge of the population and their cultural level, and implementation of ethical principles (28).

This study shed light on the perceptions of some key decision makers in the Islamic Republic of Iran about payment arrangements in the FPP. Our findings suggest four major concepts about the payment system: payment method, payment criteria and incentives, payment process and amount of payment. We found no definite consensus about the suitable methods of payment to FPs. Hence, attention needs to be given to the impact of various payment techniques on physicians' performance. Although most participants pointed out the emphasis on capitation, others mentioned the use of FFS as well as performance-based methods. It seems that the lack of a clear definition on how to pay FPs was the main reason for such incompatibility.

While salary payment was highlighted by the FPP policy, the real payment was, as few interviewees envisaged, based on the number of delivered healthcare services; namely, an FFS system. Some participants identified the capitation method as the main payment system in the FPP, and bonuses were paid to enhance quality and reduce physicians' reluctance to provide services. Nevertheless, some pointed out that none of the payment systems could actually compensate the complicated and important functions of FPs (29). This is why many countries that have implemented FPP have consequently used mixed payment methods that include salary, capitation, bonuses and FFS. Some advantages of this mixed payment system are motivating physicians, preventing unnecessary visits, and improving the quality of care and diagnosis (13).

Determining the payment criteria is another major concept. For example, measures such as the possibility of studying in a specialty field and receiving more bonuses are considered motivational for the physicians. Therefore, the payment may decrease if the physicians cannot preserve and maintain the assigned population, which may result in physicians' dissatisfaction (30). Delayed payments and low levels of bonuses are also regarded as reasons for physicians' dissatisfaction (31). One of the strengths of targeted payments is to encourage physicians to meet the desired standards of care and population health. Otherwise, it is likely targeted payments may act as a disincentive (11). Some participants identified that the payment rates of the FPP were inappropriate regardless of appropriate methods of payment. They believed that payments were too low in relation to the physicians' workload, which resulted in physicians' dissatisfaction. In addition, midwives as important members of the health team had to carry many inappropriate tasks, which led to their dissatisfaction, along with their unsatisfactory pay levels (24).

Lack of guidelines was one of the main problems in determining the payment rate among various service providers. For example, while accurate criteria were available to determine pay level for FPs who received higher payments, other members of the health teams often received low wages that were not appropriate for their workload and responsibilities. Continuous and successful implementation of the FPP may therefore require a fair approach financially and nonfinancially to all healthcare providers in the team.

Our findings also indicated that the payments did not occur in a single consolidated step, but in several stages and after evaluating the performance of the health team members. The staging of payments was seen as an instrument to motivate health team members. Some studies have suggested that it is better to apply a valuebased system to compensate the physicians. Such an approach can improve the long-term performance of physicians (32).

The generalization of our results is subject to certain limitations. Although we tried to conduct a comprehensive search of the subject in relevant public electronic media, it is likely that some information was 
overlooked. The interpretations of the research team may be different from what was intended by the participants. The researchers could not discuss the issues with some participants who were interviewed by the media; this was addressed by interviewing other participants in the field. Nonetheless, our study was validated in three ways. First, different data sources were used, including documents, literature, media news and interviews, which allowed for a high triangulation (33). Second, respondents from different organizations were interviewed. Third, codes and themes were developed and reviewed by all members of the research team as a check on bias.

\section{Conclusion}

Although implementing an FPP is a major step to improve public health and equal access to health services in urban areas, our study shows that the Iranian health system has started on the road of a difficult journey. Moreover, it seems that the mechanisms of payment in the health sector are weak and have no transparency. A blurred combination of criteria makes unclear the process for determining payment in the health system. Hence, it is recommended that the political and professional opinions of key stakeholders should be taken into consideration prior to developing appropriate payment mechanisms and financial incentives for the FPP.

\section{Acknowledgements}

We are grateful to all individuals who gave their time and made this work possible.

Funding: The study was funded by departmental resources.

Competing interests: None declared.

\section{Le système de paiements du programme de médecins de famille en zone urbaine en République islamique d'Iran : est-il adapté ? \\ Résumé}

Contexte : Le système de paiements joue un rôle central en vue de la mise en œuvre de politiques dans le secteur de la santé. Un accès équitable aux soins de santé est le principe fondamental qui sous-tend ce système.

Objectifs : La présente étude avait pour objet d'examiner certains aspects du système de paiements du Programme de médecins de famille en zone urbaine dans le cadre du système de santé de la République islamique d'Iran.

Méthodes : Il s'agissait d'une étude qualitative. Nous avons obtenu les données par l'intermédiaire d'informateurs clés ainsi que dans la littérature, à la fois officielle et grise. L'analyse des données a été effectuée à l'aide de méthodes d'analyse de contenu.

Résultats : Nous avons étudié une série de concepts liés au système de paiements du Programme de médecins de famille. En fusionnant les expressions semblables, nous avons réparti les résultats selon quatre thèmes principaux : les modes de paiement, les critères de paiement et les incitations, les processus de paiement et le montant des paiements.

Conclusions: Les Programmes de médecins de famille ont l'obligation de suivre des méthodes de mise en œuvre accessibles. Il semble que les mécanismes de paiement dans le secteur de la santé soient peu performants et manquent de transparence. Un mélange confus de critères donne lieu à un processus imprécis qui ne permet pas de déterminer le modèle de paiement. Il est recommandé de prendre en compte les avis des principaux intervenants avant d'élaborer des mécanismes de paiement et des incitations financières.

$$
\begin{aligned}
& \text { نظام دفع التكاليف في برنامج طبيب الأسرة الحضرية في جمهورية إيران الإسلامية: هل هو مناسب؟ }
\end{aligned}
$$

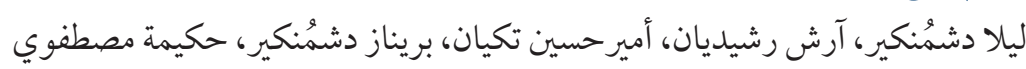

$$
\begin{aligned}
& \text { الخالاصة } \\
& \text { الخلفية: يعتبر نظام دفع التكاليف ضرورياً من أجل تنفيذ السياسات في القطاع الصحي. والمبدأ الرئيسي في نظام دفع التكاليف هو الوصول العادل } \\
& \text { لخدمات الرعاية الصحية. } \\
& \text { الهدف: دراسة جوانب نظام دفع التكاليف في برنامج طبيب الأسرة الحضرية في النظام الصحي في جمهورية إيران الإسلامية. } \\
& \text { طرق البحث: هذه دراسة وصفية، حصلنا فيها على البيانات من الأشخاص الرئيسيين المبلغين عنها ومن المنشورات الرسمية التي لم توزَّع على لئل }
\end{aligned}
$$

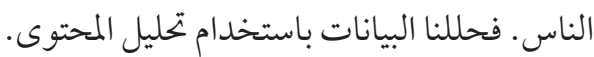

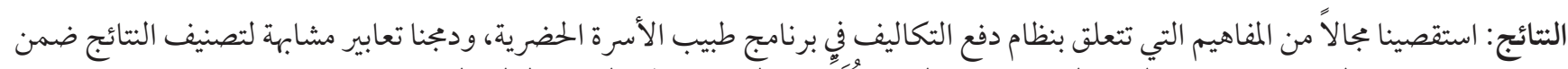

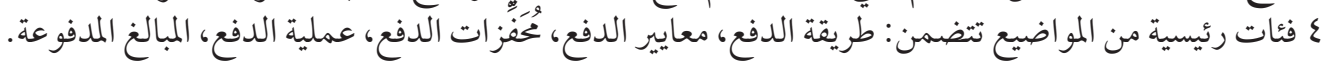




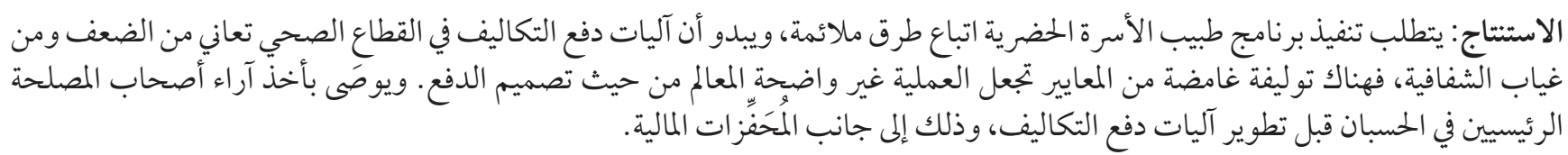

\section{References}

1. van Weel C, Rosser WW. Improving health care globally: a critical review of the necessity of family medicine research and recommendations to build research capacity. Ann Fam Med. 200405 26;2 Suppl 2:S5-16. http://dx.doi.org/10.1370/afm.194 PMID:15655089

2. Villanueva T. Family Medicine, the specialty of the future: the Portuguese situation within the European context. Int Arch Med. 200911 11;2(1):36. http://dx.doi.org/10.1186/1755-7682-2-36 PMID:19906299

3. Brocklehurst P, Price J, Glenny AM, Tickle M, Birch S, Mertz E, et al. The effect of different methods of remuneration on the behaviour of primary care dentists. Cochrane Database Syst Rev. 201311 6;(11):CDoog853. PMID:24194456

4. Schroeder SA, Frist W; National Commission on Physician Payment Reform. Phasing out fee-for-service payment. N Engl J Med. 2013 May 23;368(21):2029-32. http://dx.doi.org/10.1056/NEJMsb1302322 PMID:23534546

5. VanLare JM, Conway PH. Value-based purchasing - national programs to move from volume to value. N Engl J Med. 2012 Jul 26;367(4):292-5. http://dx.doi.org/10.1056/NEJMp1204939 PMID:22830460

6. Friedberg MW, Chen PG, White C, Jung O, Raaen L, Hirshman S, et al. Effects of health care payment models on physician practice in the United States. Santa Monica: RAND Corporation; 2015 (https://www.rand.org/pubs/research_reports/RR869.html, accessed 9 November 2017).

7. Grytten J. Models for financing dental services. A review. Community Dent Health. 2005 Jun;22(2):75-85. PMID:15984132

8. Nyweide DJ, Lee W, Cuerdon TT, Pham HH, Cox M, Rajkumar R, et al. Association of Pioneer Accountable Care Organizations vs traditional Medicare fee for service with spending, utilization, and patient experience. JAMA. 2015 Jun 2;313(21):2152-61. http:// dx.doi.org/10.1001/jama.2015.4930 PMID:25938875

9. Ikegami N. Fee-for-service payment - an evil practice that must be stamped out? Int J Health Policy Manag. 2015 02 6;4(2):57-9. http://dx.doi.org/10.15171/ijhpm.2015.26 PMID:25674568

10. Kolozsvári LR, Orozco-Beltran D, Rurik I. Do family physicians need more payment for working better? Financial incentives in primary care. Aten Primaria. 2014 May;46(5):261-6. http://dx.doi.org/10.1016/j.aprim.2013.12.014 PMID:24721041

11. Giuffrida A, Gosden T, Forland F, Kristiansen IS, Sergison M, Leese B, et al. Target payments in primary care: effects on professional practice and health care outcomes. Cochrane Database Syst Rev. 2000;4(3):CDoo0531. PMID:10908475

12. Quinn K. The 8 basic payment methods in health care. Ann Intern Med. 2015 Aug 18;163(4):300-6. http://dx.doi.org/10.7326/M142784 PMID:26259075

13. Gosden T, Forland F, Kristiansen IS, Sutton M, Leese B, Giuffrida A, et al. Capitation, salary, fee-for-service and mixed systems of payment: effects on the behaviour of primary care physicians. Cochrane Database Syst Rev. 2000; (3):CDoo2215. PMID:10908531

14. Kecmanovic M, Wilkins R. Accounting for salary sacrificed components of wage and salary income. Australian Government Department of Social Services; 2011 (http://flosse.dss.gov.au/fahcsiajspui/handle/10620/3527, accessed 9 November 2017).

15. Berenson RA, Rich EC. US approaches to physician payment: the deconstruction of primary care. J Gen Intern Med. 2010 Jun;25(6):613-8. http://dx.doi.org/10.1007/s11606-010-1295-z PMID:20467910

16. Marchildon GP. Canada: health system review. Health Systems in Transition. 2013;15(1):1-179 (http://www.euro.who.int/_data/ assets/pdf_file/oo11/181955/e96759.pdf, accessed 20 January 2018).

17. Agyepong IA, Aryeetey GC, Nonvignon J, Asenso-Boadi F, Dzikunu H, Antwi E, et al. Advancing the application of systems thinking in health: provider payment and service supply behaviour and incentives in the Ghana National Health Insurance Scheme-a systems approach. Health Res Policy Syst. 2014 Aug 5;12(35):10.1186. http...dx.doi.org/10.1186/1478-4505-12-35 PMID:25096303

18. Rodwin VG. The health care system under French national health insurance: lessons for health reform in the United States. Am J Public Health. 2003 Jan;93(1):31-7. http://dx.doi.org/10.2105/AJPH.93.1.31 PMID:12511380

19. Yardim MS, Cilingiroglu N, Yardim N. Catastrophic health expenditure and impoverishment in Turkey. Health Policy. 2010 Jan;94(1):26-33. http://dx.doi.org/10.1016/j.healthpol.2009.08.006 PMID:19735960

20. Tatar M, Mollahaliloglu S, Sahin B, Aydın S, Maresso A, Hernández-Quevedo C. Turkey: health system review. Health Systems in Transition. 2011;13(6):1-186 (http://www.euro.who.int/_data/assets/pdf_file/0006/158883/e96441.pdf, accessed 20 January 2018).

21. Khayatzadeh-Mahani A, Takian A. Family physician program in Iran: considerations for adapting the policy in urban settings. Arch Iran Med. 2014 Nov;17(11):776-8. http://dx.doi.org/ 0141711/AIM.0012 PMID:25365620

22. Takian A, Doshmangir L, Rashidian A. Implementing family physician programme in rural Iran: exploring the role of an existing primary health care network. Fam Pract. 2013 Oct;30(5):551-9. http://dx.doi.org/10.1093/fampra/cmt025 PMID:23788202

23. Lebaron SW, Schultz SH. Family medicine in Iran: the birth of a new specialty. Fam Med. 2005 Jul-Aug;37(7):502-5. PMID:15988644 
24. Jabbari H, Pezeshki MZ, Naghavi-Behzad M, Asghari M, Piri R, Bakhshian F. What is the relationship between family physicians' job satisfaction associated and their educational performance? J Anal Res Clin Med. 2015;3(1):30-6. http://dx.doi.org/10.15171/ jarcm.2015.005

25. Pope C, Ziebland S, Mays N. Qualitative research in health care. Analysing qualitative data. BMJ. 2000 Jan 8;320(7227):114-6. http://dx.doi.org/10.1136/bmj.320.7227.114 PMID:10625273

26. Forrest CB. Primary care in the United States: primary care gatekeeping and referrals: effective filter or failed experiment? BMJ. 2003 Mar 29;326(7391):692-5. http://dx.doi.org/10.1136/bmj.326.7391.692 PMID:12663407

27. Levesque J-F, Pineault R, Hamel M, Roberge D, Kapetanakis C, Simard B, et al. Emerging organisational models of primary healthcare and unmet needs for care: insights from a population-based survey in Quebec province. BMC Fam Pract. 201207 2;13(1):66. http://dx.doi.org/10.1186/1471-2296-13-66 PMID:22748060

28. Kutzin J. A descriptive framework for country-level analysis of health care financing arrangements. Health Policy. 2001 Jun;56(3):171-204. http://dx.doi.org/10.1016/So168-8510(00)00149-4 PMID:11399345

29. Yarnall KS, Østbye T, Krause KM, Pollak KI, Gradison M, Michener JL. Family physicians as team leaders: "time" to share the care. Prev Chronic Dis. 2009 Apr;6(2): A59. PMID:19289002

30. Qian F, Lim MK. Professional satisfaction among Singapore physicians. Health Policy. 2008 Mar;85(3):363-71. http://dx.doi. org/10.1016/j.healthpol.2007.09.010 PMID:18029047

31. Arab M, Torabipour A, Rahimifrooshani A, Rashidian A, Fadai N, Askari R. Factors affecting family physicians' drug prescribing: a cross-sectional study in Khuzestan, Iran. Int J Health Policy Manag. 2014 10 20;3(7):377-81. http://dx.doi.org/10.15171/ijhpm.2014.103 PMID:25489595

32. Kessels R, Van Herck P, Dancet E, Annemans L, Sermeus W. How to reform western care payment systems according to physicians, policy makers, healthcare executives and researchers: a discrete choice experiment. BMC Health Serv Res. 201505 6;15(1):191. http://dx.doi.org/10.1186/s12913-015-0847-7 PMID:25943469

33. Denzin NK, Lincoln YS (editors). Collecting and interpreting qualitative materials. Thousand Oaks, CA: SAGE Publications; 2008. 